\title{
Association between Neospora caninum seropositivity and reproductive disorders in girolando cows
}

\author{
[Associação entre a soropositividade para Neospora caninum e distúrbios reprodutivos \\ em vacas girolando] \\ V.G. Gaia ${ }^{1}$, G.F. Grillo ${ }^{1}$, M.R.B. Mello ${ }^{*}$, H.B. Palhano ${ }^{3}$, A.F. Silva ${ }^{4}$ \\ ${ }^{1}$ Aluno de pós-graduação - Universidade Federal Rural do Rio de Janeiro - Seropédica, RJ \\ ${ }^{2}$ Instituto de Zootecnia - Universidade Federal Rural do Rio de Janeiro - Seropédica, RJ \\ ${ }^{3}$ Instituto de Ciências Biológicas e da Saúde - Universidade Federal Rural do Rio de Janeiro - Seropédica, RJ \\ ${ }^{4}$ Instituto de Medicina Veterinária - Universidade Federal Rural do Rio de Janeiro - Seropédica, RJ
}

\begin{abstract}
The aim of this study was to investigate the presence of anti-Neospora caninum antibodies in Girolando cows, in order to evaluate the association between seropositivity and reproductive disorders. Blood samples were collected from 40 dairy cows in their reproductive phase from the cranial superficial epigastric vein. The blood samples were tested using the Indirect Fluorescence Antibody Test (IFAT) to detect antiN.caninum antibodies. The serological results were used to verify whether there was any association with the manifestation of reproductive disorders based on data from the records of reproductive history from 2017 to 2018 as well as the clinical observations of the herd throughout this study. The Fisher exact test was used to verify the existence of an association between the serology and reproductive disorders, adopting a $95 \%$ confidence level. The serological results showed a $27.5 \%$ seroprevalence in the herd for $N$. caninum, however, after statistical analysis, no association between seropositivity and reproductive disorders was found in the evaluated herd. Although the studied population is infected with Neospora caninum, we can infer that anti-Neospora caninum antibodies present in Girolando dairy cows at the UFRRJ Dairy Cattle Facility are not associated with the occurrence of reproductive disorders.
\end{abstract}

Keywords: neosporosis, dairy cattle, IFAT, reproduction, abortion

\section{RESUMO}

O objetivo deste estudo foi investigar a presença de anticorpos anti-Neospora caninum em vacas Girolando, avaliando-se a associação entre a soropositividade e os distúrbios reprodutivos. Foram coletadas amostras de sangue da veia epigástrica superficial cranial de 40 vacas leiteiras em fase reprodutiva, sendo as amostras testadas pela reação de imunofluorescência indireta (RIFI) para detecção de anticorpos anti-N. caninum. A partir dos resultados sorológicos, foi realizada a verificação de associação, ou não, com a manifestação de distúrbios reprodutivos, coletados nos registros de histórico reprodutivo entre 2017 e 2018 e observações do rebanho no transcorrer do estudo. O teste exato de Fisher foi utilizado para verificar a existência de associação entre a sorologia e os distúrbios reprodutivos, adotando-se nível de confiança de 95\%. O resultado do estudo demonstrou uma soroprevalência no rebanho de 27,5\% para $\mathrm{N}$. caninum, contudo, após análise estatística, não foi confirmada a associação entre soropositividade e distúrbios reprodutivos no rebanho avaliado. Apesar de a população estudada estar infectada com o Neospora caninum, pode-se inferir que anticorpos anti-Neospora caninum presentes em vacas leiteiras Girolando do Setor de Bovinocultura de Leite da UFRRJ não estão associados à ocorrência de distúrbios reprodutivos.

Palavras-chave: neosporose, gado de leite, RIFI, reprodução, aborto

Recebido em 25 de maio de 2020

Aceito em 28 de julho de 2020

*Autor para correspondência (corresponding author)

E-mail: mmello@ufrrj.br 


\section{INTRODUCTION}

Neosporosis is a parasitic disease of worldwide distribution that is caused by a mandatory intracellular protozoan parasite Neospora caninum. Bovine neosporosis was associated with abortion outbreaks for the first time in 1987, in a study carried out with a herd of dairy cattle located in the state of New Mexico, United States of America (USA) (Thilsted and Dubey, 1989). This disease has been the target of several research projects worldwide since its description, mainly because it affects the reproductive system of cattle, causing economic losses in livestock (Lefkaditis et al., 2020). Vertical transmission is the main form of infection and maintenance of infection in cattle herds. Another pathway is horizontal transmission that occurs through the ingestion of sporulated oocysts in food or water and ingestion of tissue cysts by the intermediate hosts.

Abortion is the main clinical sign in beef or dairy herds, and can occur from the third to the ninth month of gestation in cows of any age group, but they occur mainly between the fifth and sixth months. Serology is used as a diagnostic method in epidemiological studies of abortions caused by $N$. caninum, in order to evaluate the exposure and risk of infection in a herd, and it is an important tool for monitoring, controlling and preventing disease in bovine herds. Furthermore, serology tests should be carried out before introducing new animals into the herd (Noaman and Nabinejad, 2020). Different seroprevalence results must be compared with caution, due to the use of different serological analysis methods and different values for the applied cutoff point (Dubey et al., 2007, Lefkaditis et al., 2020).

A few epidemiological studies of bovine neosporosis have been performed in different regions of the State of Rio de Janeiro. Such studies highlight the importance of bovine neosporosis and help understand its impacts on livestock. The Dairy Cattle Facility of the Universidade Federal Rural do Rio de Janeiro (UFRRJ) is a nucleus of teaching, research and knowledge generation for academic training and dissemination of knowledge and practices for the state cattle farmers. The aim of this study was to investigate the presence of anti-Neospora caninum antibodies in Girolando females in this Facility, evaluating the association between seropositivity and reproductive disorders in the studied population.

\section{MATERIAL AND METHODS}

This is a cross-sectional study evaluating cause and effect simultaneously, considering exposed (seropositive) and unexposed (seronegative) females as the cause and the reproductive disorders as an effect of the exposure to the etiologic agent. The study was approved by the Ethics Committee for Animal Experimentation of the Universidade Federal Rural do Rio de Janeiro (UFRRJ-Brazil), under process number CEUA-IB 005/2014.

This study was carried out at the Dairy Cattle Facility of UFRRJ, located in Seropédica-RJ (latitude: $22^{\circ} 46^{\prime} 56$. S; longitude: $43^{\circ} 39^{\prime} 41$. W). The Facility has a herd of 130 animals (cows, calves, heifers, bulls). Blood samples were collected from 40 Girolando dairy cows, in their reproductive phase, multiparous, dry or lactating with ages ranging from 4 to 8 years old. The herd at the UFRRJ Facility is raised using a semiintensive system.

Brucellosis and Tuberculosis is controlled for the whole herd as recommended by the National Brucellosis and Tuberculosis Control and Eradication Program (PNCEBT), immunization is with the B19 vaccine for females from three to eight months old and animals over 24 months are tested for Brucellosis and Tuberculosis. Vaccines were also carried out to prevent FMD, Leptospirosis and Rabies. The control of endoparasites and ectoparasites (helminths, ticks and botfly larva) in addition to mastitis was carried out strategically in accordance with the protocols planned by the UFRRJ veterinarian, responsible for the Facility.

The blood samples were collected to detect antiNeospora caninum antibodies for the 40 cows, all on the same day, through the cranial superficial epigastric vein with a $5 \mathrm{ml}$ Vacutainer® tube. After collection and identification, they were all quickly transported in a cooler with recyclable ice to the Coccidia and Coccidiosis Laboratory (LCC), where they were kept refrigerated. After 24 hours to allow the clot to retract, the samples were centrifuged at $5,000 \mathrm{rpm}$ for 10 minutes to obtain the sera. These sera samples were placed in $1.5 \mathrm{ml}$ plastic microtubes, in duplicate, at a 
temperature of $-20^{\circ} \mathrm{C}$ until required for Indirect Fluorescence Antibody Test (IFAT). These results showed which animals were seropositive and which were seronegative for anti- $N$. caninum antibodies.

The IFAT test for anti-N.caninum antibodies in cattle was performed at the Laboratory of Coccidia and Coccidiosis (LCC) of the Department of Animal Parasitology at UFRRJ. The entire procedure was performed according to the manufacturer's guidelines (Imunoteste ${ }^{\circledR}$, Neopora caninum - Bovino, Imunodot, Jaboticabal, SP, Brazil) for the detection of antiNeospora caninum antibodies in cattle. After carrying out the protocol, the slide was assembled with a coverslip and glycerin, and then observed using the epifluorescence system of the microscope (Zeiss Axio® Lab a1) with a 400x objective lens. The samples were considered positive when they showed a clear greenish fluorescence around the entire cell periphery of the tachyzoites. Partial or apical reactions were interpreted as negative.

The serological results demonstrated the existence or not of an association with the manifestation of reproductive disorders through the analysis and evaluation of the reproductive history of the cows over the last two years (2017-2018) and the close monitoring of the animals throughout this study. The reproductive history of the cows was taken from the technical files with zootechnical and sanitary information of the cows at the UFRRJ Dairy Cattle Facility. The reproductive disorders evaluated were: return to estrus after a long period of service and delivery interval; estrus repetition after three successive inseminations (conventional AI or Timed AI) which we classified as repeat breeder cow; return to heat after a natural breed; abortions at any stage of pregnancy; placental retention; nonspecific uterine infections; mummified and macerated fetuses; embryonic absorption and stillbirths.

The Fisher exact test was used to verify the existence of an association between seropositive cows with and without reproductive disorders and seronegative cows with and without reproductive disorders, adopting a significance level of 5\%, and reliability of $95 \%$. Exposure to $N$. caninum as a risk factor for the occurrence of reproductive disorders was evaluated using the matrix proposed by Pereira (1995) for the analysis of odds ratio (OR) in cross-sectional studies, with a $95 \%$ confidence level (0.34-6.55).

\section{RESULTS}

The analyses of the 40 bovine serum samples showed that $27.5 \%(11 / 40)$ were seropositive for anti- $N$. caninum antibodies. However, among the 40 cows analyzed, $36.4 \%$ (4/11) of seropositive and $27.6 \%(8 / 29)$ of seronegative presented some type of reproductive disorder (Table 1). The most frequent disorder observed in bovine females was a repeat breeding after at least three successive inseminations.

No significant association was found between anti-Nesospora caninum serology and reproductive disorders at the Dairy Cattle Facility. There were 12 cows (30\%) out of the 40 animals tested that had reproductive disorders and only 4 of these were seropositive while the remaining 8 were seronegative. Among this group of 40 animals selected, 28 did not have any reproductive disorders, however, 7 of these animals were seropositive while 21 were seronegative. In total there were 11 seropositive animals $(27.5 \%)$ and 29 seronegative $(72.5 \%)$ in the selected sample. The reproductive disorders observed in this study are within the values considered normal and expected in a dairy herd.

The exposure to $N$. caninum as a risk factor for the occurrence of reproductive disorders was calculated from the odds ratio analysis with an OR value of 1.5. The result showed that the exposure (seropositive) to the etiologic agent as a risk factor was one and a half times greater for the occurrence of reproductive disorders compared to the unexposed group (seronegative), as shown in Table 2. 
Table 1. Reproductive disorders in Neospora caninum seropositive and seronegative Girolando cows at the Dairy Cattle Facility of Universidade Federal Rural do Rio de Janeiro

\begin{tabular}{|c|c|c|c|}
\hline Animal & Serology & Age (months) & Reproductive disorders \\
\hline 1 & - & 145 & ND \\
\hline 2 & - & 138 & ND \\
\hline 3 & + & 134 & ND \\
\hline 4 & + & 131 & ND \\
\hline 5 & - & 117 & ND \\
\hline 6 & + & 117 & ND \\
\hline 7 & - & 117 & ND \\
\hline 8 & - & 115 & LSP 210 days \\
\hline 9 & - & 110 & $\mathrm{AB}$ \\
\hline 10 & - & 109 & RE after third AI \\
\hline 11 & - & 109 & LSP 382 days \\
\hline 12 & - & 109 & ND \\
\hline 13 & - & 103 & RE after third AI \\
\hline 14 & - & 101 & ND \\
\hline 15 & + & 93 & ND \\
\hline 16 & - & 93 & LSP 286 days \\
\hline 17 & - & 90 & ND \\
\hline 18 & - & 79 & ND \\
\hline 19 & - & 77 & ND \\
\hline 20 & - & 77 & ND \\
\hline 21 & - & 76 & ND \\
\hline 22 & + & 74 & $\mathrm{AB}$ \\
\hline 23 & - & 73 & ND \\
\hline 24 & - & 72 & ND \\
\hline 25 & - & 71 & ND \\
\hline 26 & - & 68 & ND \\
\hline 27 & + & 62 & ND \\
\hline 28 & + & 60 & ND \\
\hline 29 & - & 60 & ND \\
\hline 30 & + & 58 & $\mathrm{AB}$ \\
\hline 31 & - & 54 & ND \\
\hline 32 & - & 54 & RE after third AI \\
\hline 33 & + & 53 & ND \\
\hline 34 & + & 53 & $\mathrm{RE}$ after third AI \\
\hline 35 & - & 52 & ND \\
\hline 36 & + & 50 & RE after third AI \\
\hline 37 & - & 125 & ND \\
\hline 38 & - & 127 & ND \\
\hline 39 & - & 120 & $\mathrm{AB}$ \\
\hline 40 & - & 122 & ND \\
\hline
\end{tabular}

Table 2. Evaluation of the exposition to Neospora caninum as a risk factor for reproductive disorders in Girolando cows at the Dairy Cattle Facility of Universidade Federal Rural do Rio de Janeiro

\begin{tabular}{lcccc}
\hline $\begin{array}{c}\text { Exposition to the } \\
\text { factor }\end{array}$ & \multicolumn{2}{c}{ Reproductive Disorders } & \multirow{2}{*}{ Total } & $\begin{array}{c}\text { Disorder } \\
\text { Prevalence }\end{array}$ \\
\cline { 2 - 3 } Seropositive & YES & 7 & 11 & $36.4 \%$ \\
Seronegative & 4 & 21 & 29 & $27.6 \%$ \\
Total & 8 & 28 & 40 & $30 \%$ \\
\hline Risk: Prevalence Ratio $=36.4 / 27.6=1.3 ;$ OR $=(4 \times 21) /(7 \times 8)=1.5 ;$ Confidence level $95 \%(0.34-6.55)$
\end{tabular}




\section{DISCUSSION}

The seroprevalence of $27.5 \%$ observed in this study conducted with the Girolando herd of the UFRRJ Dairy Cattle Facility is within the average values for Brazil, found in the literature which vary from $9.1 \%$ up to $91.2 \%$ (Bruhn et al., 2013; Langoni et al., 2013; Klauck et al., 2016; AquinoDiniz et al., 2019, Lefkaditis et al., 2020). This wide variation is probably related to the different diagnostic methods and cutoff points used in those studies, in addition to the use of cows of different ages and different breeds. The knowledge concerning the seroprevalence of N.caninum is essential to understand the losses that affect livestock and to help outline the strategic planning of this sector. Two studies have investigated this topic in the state of Rio de Janeiro. Ragozo et al. (2003) found a $22.7 \%$ seroprevalence in a survey conducted in Resende and Munhoz et al. (2006) found a seroprevalence of $23 \%$ in Rio Claro, both locations are close to Seropedica. These results show that the prevalence in our study is similar to previous studies and demonstrates that the disease is present in the herds of Rio de Janeiro state. Therefore, this topic is important and should be investigated further.

In other countries, the prevalence for $N$. caninum is between $1.0 \%$ and $80.1 \%$, again the value of $27 \%$ found in our study is in the intermediate values (Schares et al., 2009; Eiras et al., 2011). In Latin America neosporosis is considered an emerging disease in dairy cattle and is responsible for economic losses, related to reproductive disorders with differences in the seroprevalence of N.caninum of $11.3 \%$ in Venezuela and $45 \%$ in Colombia, using the IFAT and ELISA, respectively (Lista-Alvez et al., 2006; Medellin et al., 2017).

In this study, IFAT was used to detect the presence of antibodies to $N$. caninum in dairy cows, since epidemiological studies in various hosts have shown that this test has a high sensitivity for $N$. caninum and a low occurrence of cross-reaction between $N$ caninum and $T$. gondii (Haddad et al., 2005). The sensitivity of the serological test for animals chosen at random is less than for animals that have just had an abortion. Tests with animals chosen at random can generate false-negative results, underestimating the true seroprevalence (Dubey and Schares, 2006).
The characteristics of the region, the management system and type of production of the farms and the way the animals and herds are selected, are not always well described in studies carried out in Brazil. In addition, different patterns of farms management, breed of animals, risk factors, methods of diagnosis and cut-off points tend to hinder any type of comparison between studies, both nationally and internationally. Another important factor is the selection of farms by convenience, with abortion as a criterion, which may overestimate the results in relation to random sample selection. Another relevant factor in this study is the use of adult cows, since the probability of seropositive results is greater when compared to younger animals, due to the longer time of exposure to the environment, thus increasing the risk of becoming infected through horizontal transmission (Dubey et al., 2007). In Ethiopia and Croatia, studies have shown an association between older animals and the presence of anti- $N$. caninum antibodies (Beck et al., 2010; Asmare et al., 2013). Dairy cattle are more likely to be seropositive for $N$. caninum, due to the favorable management conditions of these farms for the transmission of infection such as the: greater longevity of dairy cows compared to beef herds. In addition, the replacement of the dairy herd with animals from the same farm, can transmit the infection both by transplacental and horizontal pathways (Eiras et al., 2011).

In the present study, no association was observed between seropositivity and reproductive disorders, which differs from the studies by Bruhn et al. (2013), Langoni et al. (2013) and Fávero et al. (2017), who reported and confirmed this association. However, our results are similar to the results observed by Medellín et al. (2017), where 1000 adult dairy cows of different breeds were analyzed. The diagnostic method used was ELISA and no association was found between seropositivity and reproductive disorders. In another study by Paz et al. (2007) the authors observed the occurrence of antibodies against $\mathrm{N}$. caninum in a herd of embryo-recipient beef cows, reared in an extensive system in the state of Mato Grosso do Sul. When the authors evaluated the pregnancy rate of seropositive recipients for $N$ caninum, no association with seropositivity was found. Other studies are also in line with the results observed in this research, such as Ogawa et al. (2005) and López-Gatius et al. (2005) in 
which seropositivity was not related to reproductive disorders.

The lack of association can be explained by some factors. As reported in the methodology, when adult cows are used, which according to Jensen $e t$ al. (1999), tend to obtain more stable levels of antibodies due to the prolonged antigenic stimulation after repeated reactivations of the infection and with that they become resistant to $N$. caninum, and therefore have less impact on their reproductive performance. In another study, addressing risk factors for abortion, the number of lactations were identified as a factor of resistance to $\mathrm{N}$. caninum in dairy cows that were seropositive for $N$. caninum (Thurmond and Hietala, 1997). However, a study by Jensen et al. (1999) pointed out contrary results by concluding that increasing age is a risk factor for abortion of bovine females.

The animals of the herd studied here are a crossbred (Girolando), which is another factor that confers resistance to $N$. caninum infection, as reported by Sala et al. (2018), with results that support the hypothesis of a close association between this bovine breed and the frequency of infection by $N$. caninum. Asmare et al. (2013) reported that pure breed animals are more susceptible to neosporosis than crossbred animals. In addition, is the fact that the studied population (Dairy Cattle Facility - UFRRJ) undergoes monitoring and health control according to their epidemiological demands.

Therefore, as far as possible, the individuals that compose this population do not go through factors that alter their immunity during pregnancy such as stress and malnutrition, as pointed out by Bartels et al. (1999) as risk factors. A study by Waldner (2005) revealed that a low body condition score (BCS less than 2.5) increases, together with the increase in the levels of specific antibodies to $N$. caninum, the chances of beef cows showing reproductive failures.

Furthermore, the seroprevalence of a herd can change over the years, with fluctuations in the results. Therefore, despite the fact that no association with reproductive disorders was observed in the present study, in a future study on reproductive efficiency indicators there may be a negative evolution of the reproductive efficiency of the herd due to this pathophysiology that is widely studied and reported in cattle. In the occurrence of stressors that can depress the immune status of cows at risk (pregnant cows with gestational age between 100 and 260 days), the probability of an outbreak of endemic abortions is increased, through the reactivation of $N$. caninum and reinfection of the matrix and infection of the fetus through endogenous transplacental transmission (Dubey and Schares, 2006).

Some authors suggest that other infections, by causing immunosuppression, may favor the infection and reactivation of $N$. caninum. Vanleeuwen et al. (2010) demonstrated a positive association between seropositive animals with bovine viral diarrhea. For a future work we can suggest the use of definitive diagnostic techniques, such as immunohistochemistry and PCR, associated with serology and make the control based on the prevention of horizontal transmission as an important factor to prevent an increase of the seroprevalence in a herd. In addition, more studies on the seroprevalence of Neospora caninum are needed, due to the very few studies in the State of Rio de Janeiro. In general, there is a real demand for new epidemiological surveys and analyses of the impacts on the reproductive efficiency of herds.

\section{CONCLUSIONS}

The results obtained in this study show that there was no association between the presence of antibodies to Neospora caninum and reproductive disorders in the bovine population studied.

\section{REFERENCES}

AQUINO-DINIZ, L.V.; MINUTTI, A.F.; SOUZA, L.N.B. et al. Vertical transmission of Neospora caninum in bovine fetuses from a slaughterhouse in Brazil. Trop. Anim. Health Prod., v.51, p.1751-1755, 2019.

ASMARE, K.; REGASSA, F.; ROBERTSON, L.J.; SKJERVE, E. Seroprevalence of Neospora caninum and associated risk factors in intensive or semi-intensively managed dairy and breeding cattle of Ethiopia. Vet. Parasitol., v.193, p.85-94, 2013. 
BARTELS, C.J.M.; WOUDA, W.; SCHUKKEN, Y.H. Risk factors for Neospora caninumassociated abortion storms in dairy herds in the Netherlands (1995 to 1997). Theriogenology, v.52, p.247-257, 1999.

BECK, R.; MARINCULIĆ, A.; MIHALJEVIĆ, Ž. et al. Seroprevalence and potential risk factors of Neospora caninum infection in dairy cattle in Croatia. Vet. Arhiv., v.80, p.163-171, 2010.

BRUHN, F.R.P.; DAHER, D.O.; LOPES, E. et al. Factors associated with seroprevalence of Neospora caninum in dairy cattle in southeastern Brazil. Trop. Anim. Health Prod., v.45, p.10931098, 2013.

DUBEY, J.P.; SCHARES, G. Diagnosis of bovine neosporosis. Vet. Parasitol., v.140, p.1-34, 2006.

DUBEY, J.P.; SCHARES, G.; ORTEGA-MORA, L.M. Epidemiology and control of neosporosis and Neospora caninum. Clin. Microbiol. Rev., v.20, p.323-367, 2007.

EIRAS, C.; ARNAIZ, I.; ALVAREZ-GARCIA, G. et al. Neospora caninum seroprevalence in dairy and beef cattle from the northwest region of Spain, Galicia. Prev. Vet. Med., v.98, p.128-132, 2011.

FÁVERO, J.F.; SILVA, A.S.; CAMPIGOTTO, G. et al. Risk factors for Neospora caninum infection in dairy cattle and their possible causeeffect relation for disease. Microbiol. Pathog., v.110, p.202-207, 2017.

HADDAD, J.P.A.; DOHOO, I.R.; VANLEEWEN, J.A. A review of Neospora caninum in dairy and beef cattle - a Canadian perspective. Can. Vet. J., v.46, p.230-243, 2005.

JENSEN, A.M.; BJORKMAN, C.; KJELDSEN, A.M. et al. Association of Neospora caninum seropositivity with gestation number and pregnancy outcome in Danish dairy herds. Prev. Vet. Med., v.40, p.151-163, 1999.

KLAUCK, V.; MACHADO, G.; PAZINATO, R. et al. Relation between Neospora caninum and abortion in dairy cows: Risk factors and pathogenesis of disease. Microbiol. Pathog., v.92, p.46-49, 2016.

LANGONI, H.; SILVA, A.V.; KATAGIRI, S. et al. Avaliação sorológica para Neospora caninum em propriedades de bovinos leiteiros com alterações reprodutivas. Vet. Zootec., v.20, p.124130, 2013.
LEFKADITIS, M.; MPAIRAMOGLOU, R.; SOSSIDOU, A. et al. Neospora caninum, a potential cause of reproductive failure in dairy cows from Northern Greece. Vet. Parasitol. Reg. Stud Rep., v.19, p.1-5, 2020.

LISTA-ALVES, D; PALOMARES-NAVEDA, R.; GARCIA, F. et al. Serological evidence of Neospora caninum in dual-purpose cattle herds in Venezuela. Vet. Parasitol., v.136, p.347-349, 2006.

LÓPEZ-GATIUS, F.; SANTOLARIA, P.; ALMERÍA, S. Neospora caninum infection does not affect the fertility of dairy cows in herds with high incidence of Neospora associated abortions. J. Vet. Med. B. Infect. Dis. Vet. Public Health, v.52, p.51-53, 2005.

MEDELLÍN, M.O.P.; ANAYA, A.M.D.; BECERRA, R.J.A. Association between reproductive variables and anti Neospora caninum antibodies in dairy cattle herds from a Colombian municipality. Rev. Mex. Cienc. Pecu., v.8, p.167174, 2017.

MUNHOZ, A.D.; FLAUSINO, W.; SILVA, R.T. et al. Distribuição de anticorpos contra Neospora caninum em vacas leiteiras dos municípios de Resende e Rio Claro, Estado do Rio de Janeiro, Brasil. Rev. Bras. Parasitol. Vet., v.15, p.101-104, 2006.

NOAMAN, V.; NABINEJAD, A.R. Seroprevalence and risk factors assessment of the three main infectious agents associated with abortion in dairy cattle in Isfahan province, Iran. Trop. Anim. Health. Prod., v.52, p.2001-2009, 2020.

OGAWA, L.; FREIRE, R.L.; VIDOTTO, O. et al. Ocurrence of antibodies to Neospora caninum and Toxoplasma gondii in dairy cattle from the northern region of the Paraná State, Brazil. Arq. Bras. Med. Vet. Zootec., v.57, p.312-316, 2005.

PAZ, G.F.; LEITE, R.C.; ROCHA, M.A. Associação entre sorologia para Neospora caninum e taxa de prenhez em vacas receptoras de embriões. Arq. Bras. Med. Vet. Zootec., v.59, p.1323-1325, 2007.

PEREIRA, M.G. Epidemiologia teórica e prática. Rio de Janeiro: Guanabara Koogan, 1995, 596p. 
RAGOZO, A.M.A.; PAULA, V.S.O.; SOUZA, S.L.P. et al. Ocorrência de anticorpos antiNeospora caninum em soros bovinos procedentes de seis estados brasileiros. Rev. Bras. Parasitol. Vet., v.12, p.33-37, 2003.

SALA, G.; GAZZONIS, A.; BOCCARDO, A. et al. Using beef-breed semen in seropositive dams for the control of bovine neosporosis. Prev. Vet. Med., v.161, p.127-133, 2018.

SCHARES, G.; WILKING, H.; BOLLN, M. et al. Neospora caninum in dairy herds in SchleswigHolstein, Germany. Berl. Munch. Tierärztl. Wochenschr., v.122, p.47-50, 2009.

THILSTED, J.P.; DUBEY, J.P. Neosporosis-like abortions in a herd of dairy cattle. J. Vet. Diagn. Invest., v.1, p.205-209, 1989.
THURMOND, M.C.; HIETALA, S.K. Effect of congenitally acquired Nesopora caninum infection on risk abortion and subsequent abortions in dairy cattle. Am. J. Vet. Res., v.58, p.1381-1385, 1997.

VANLEEUWEN, J.A.; HADDAD, J.P.; DOHOO, I.R. et al. Risk factors associated with Neospora caninum seropositivity in randomly sampled Canadian dairy cows and herds. Prev. Vet. Med., v.93, p.129-138, 2010.

WALDNER, C.L. Serological status for Neospora caninum, bovine viral darrhea vírus, and infectius bovine rhinitracheitis vírus at pregnacy testing and reproductive performance in beef herds. Anim. Reprod. Sci., v.90, p.219-242, 2005. 